\title{
Yabancılar ve Uluslararası Koruma Kanunu ile Göç İdaresi Bağlamında Türkiye'nin Yeni Göç Siyaseti ${ }^{1}$
}

\author{
Seçkin BAYKAL ${ }^{*}$, Levent YILMAZ **
}

$\ddot{\mathbf{O Z Z}}$

Türkiye'nin göç siyasetinin 2010 yılından beri değiştiği iddia edilmektedir. Bu iddianın iki temel dayağı bulunmaktadır. İlki, 1980'lerden sonra değişen uluslararası göç olgusundan Türkiye'nin transit ülke olarak etkilenmesidir. İkinci olarak da hızla hayat geçirilen idarî ve hukukî düzenlemelerdir. Bu çalışmada tartışılacak olan konu, yapılan idarî ve hukukî düzenlemelerin bir politika değişikliğine tekabül edip etmediğidir. Türkiye'nin göç siyasetinde, son dönemde yapılan düzenlemelerin radikal bir dönüşüm olmadığı söylenebilir. Ancak Türkiye'nin klâsik göç siyaseti modelinin revizyonundan ibaret olduğunu iddia etmek, yapılan hukukî ve idarî düzenlemeleri hafife almak olur. Türkiye'nin klâsik göç siyasetindeki coğrafî çekince meselesi korunmuş ancak coğrafî çekinceye konu olanlar için yeni statüler tanınmıştır. Ayrıca, Türk kamu yönetiminde yeni bir kurum ihdas edilmiştir. Kamu yönetimde yapılan birçok düzenleme gibi, bu kurumsal yapı da kamuoyu nezdinde ve belki de bürokrasinin içinde tam yerine oturtulabilmiş değildir.

Anahtar Kelimeler: Göç Siyaseti, Yabancılar ve Uluslararası Koruma Kanunu, Göç İdaresi

JEL Sinıflandırması: H11

\section{Turkey's New Immigration Policy in the Context of Foreigners and International Protection Act and General Directorate of Migration Management}

\begin{abstract}
It is claimed that Turkey's immigration policy has changed since 2010. This claim has two main gauntlets. First, after the 1980s, international migration is affected by the changing of Turkey as a transit country. Secondly, they are administrative and legal regulations that are rapidly implemented. The subject to be discussed in this study is whether the administrative and legal arrangements made correspond to a policy change. Turkey's immigration policy in the arrangements made in recent years, can be said that does not mean a radical change in immigration policy. However, to argue that the arrangements made consist of the revision of Turkey's classical immigration policy, it would be to underestimate the legal and administrative arrangements made. Turkey's geographical reservation in the classical immigration policy is preserved in the new arrangements; however, new status has been granted for those subject to geographical reservation. In addition, a new institution has been created in the Turkish public administration. Like many arrangements made in public administration, this institutional structure has not been able to be fall into place before the public and perhaps within the bureaucracy.
\end{abstract}

Keywords: Migration Policy, Foreigners and International Protection Law, Migration Management

JEL Classification: H11

Geliş Tarihi / Received: 18.05.2020 Kabul Tarihi / Accepted: 10.06.2020

\footnotetext{
${ }^{1}$ Bu makale “Türkiye’nin Yeni Göçmen Siyasetinin Kurumsal Yapısı: Göç İdaresi Genel Müdürlüğü” isimli yüksek lisans tezinden yararlanılarak yeni bir iddia çerçevesinde türetilmiştir.

* Arş. Gör., Nevşsehir Hacı Bektaş Veli Üniversitesi, İ̈BF, Kamu Yönetimi Bölümü, seckinbaykal@ @evsehir.edu.tr, ORCID: 0000-0001-5449-688X

** Dr. Öğr. Üyesi, Dokuz Eylül Üniversitesi, İ̈BF, Kamu Yönetimi Bölümü, levent.yilmaz@deu.edu.tr, ORCID: 0000-0002-5538-8781
} 


\section{GIRIŞ}

$\mathrm{Bu}$ çalışmada, Türkiye'nin uzun yıllardır devam eden göç siyasetinin özellikle Yabancılar ve Uluslararası Koruma Kanunu (YUKK)'nun kabul edilmesi ve bu çerçevede Göç İdaresinin kuruluşuyla klâsik çizgisinden ayrıldı ̆̆ı iddiası değerlendirilmeye çalışılacaktır. Genel olarak, Cumhuriyetin ilânından 2000'li yıllara kadar Türkiye'nin klâsik ve ana hatları değişmeyen bir göç siyaseti olduğu kabul edilmektedir. Klâsik olarak tabir edilebilecek bu siyasetin değiştiği iddiasını ortaya koymak için, haliyle, bu dönemin göç siyasetinin ana özelliklerini belirlemek gerekmektedir. Bu özellikler yasal ve kurumsal bağlamda belirlenebilir. Böylelikle, değiştiği iddia edilen göç siyasetinin de bu bağlam kapsamında -yani yasal ve kurumsal olarak- açıklaması yapılabilir. Bir bakıma karşılaştırmalı olarak eski ve yeni göç siyasetinin kaynaklarına değinmek gereklidir. Bunun yanında, söz konusu bağlamı uygulama açısından da ele almak doğu bir yol olacaktır. Böylelikle, yasal ve kurumsal düzenlemelerin pratiğe geçişini görmek mümkün olacaktır.

Çalışma sonucunda iki olasılıktan birinin ağır bastığı neticesine ulaşılması gerekmektedir. Birinci olasıllı, Türkiye'nin yeni göç siyaseti ile klâsik göç siyasetinin -bazı konjonktürel farklar içerse de- son tahlile bir devamlılık arz ettiğidir. İkinci olasılık ise yeni ve klâsik göç siyaseti arasında bir kopuşun olduğudur. Bunun ortaya konabilmesi için Türkiye'nin göç siyasetlerini, yukarıda belirtildiği gibi, yasal, kurumsal ve pratik boyutları ile açılamak gerekmektedir.

\section{TÜRKIYY'NIN KLÂSİK GÖÇ SIYYASETI}

Türkiye için göç hareketleri bağlamında bir sınıflandırma yapıldığında göç alan, göç veren ve daha önemlisi tarihi boyunca göç yolları üzerinde transit geçiş ülkesi konumunda bulunduğu söylenebilir. Cumhuriyetin ilânından sonra dönemlere ayrılarak incelenmesi görece daha kolay olsa da, Türkiye için göç hareketlerinin Osmanlı döneminden itibaren yoğun şekilde gerçekleştiği belirtilmelidir. Bu durumda göç hareketlerine bakış ve göç politikasının gelişimi önem arz etmektedir.

Politika merkezli bir bakış bağlamında, önemli göç hareketlerinden biri Osmanlı döneminde gerçekleşen Yahudi göçüdür. İstanbul'un alınmasından sonra Osmanlı'nın elinde bulundurduğu diğer topraklardan İstanbul'a doğru bir göç gerçekleşmiştir. O dönem nüfusu 50.000 civarı olan İstanbul'a gerçekleşen Yahudi göçü için, İmparatorluğun bakışının ekonomik temelli olduğu iddia edilebilir. Öncelikle böyle bir göç akımının nüfus artışıla birlikte ekonomik kalkınma sağlayacakları düşünülmüştür. Ayrıca farklı bir dine mensup topluluğun göç etmesi toplumsal hoşgörünün artmasına da katkı sağlayacaktır (Rozen, 2010: 45).

Osmanlı döneminden itibaren göç ve göçe bakış açılarını incelemek için göç yönetiminde çıkarılmış kanunların etkilerine bakmak gerekir. Cumhuriyet öncesinde yaşanan göç akımları genel olarak ekonomik ve sosyal kalkınma üzerinden değerlendirilirken Cumhuriyet sonrasında farklılaşan göç akımları yasalarla idare edilmeye başlanan bir göç yönetimi oluşturmuştur.

\subsection{Göç Mevzuatı}

\subsection{1. İskân Kanunları}

Osmanlı döneminde farklı dinlere mensup toplulukların göç etmesine alışık olan bir ülke için Cumhuriyetin ilânı sonrası özellikle Yunanistan ile yaşanan mübadele sürecinin büyük etkisiyle Türk kültürüne yakın olan ülkelerden gelen göçler ve Türk kökenlilerin göçleri etkili 
olmaya başlamıştır (Kirişçi, 2000: 93). İskân, Osmanlı zamanından itibaren fetihler sonrasında yer değiştirecek nüfus hareketlerinin sağlanmasında önem verilen bir konu olmuştur. İskân kelimesinin tanımına bakıldığında, birey ya da toplulukların yer değiştirmeleri ve yeni yerlerinde istihdam edilebilmeleri ile konut sahibi olmaları anlamları göze çarpmaktadır (Keleş, 1998: 140; Emek İnan, 2014: 84).

İskân konusunda ilk resmî adım 1860 yılında İdâre-i Umumiyye-i Muhâcirîn Komisyonu'nun kurulmasıyla atılmıştır. İskân-ı Muhacirin Talimatnâmesi komisyon tarafindan çıkarılmış ve geçmişe bakıldığında göç yönetiminin düzenlenmesinde kullanılan ilk yazılı örnek olduğu söylenebilir (Barut, 2018: 169). I. Dünya Savaşı ve sonrasında yaşanan gelişmelerle birlikte dönem nüfusunun yaklaşık üçte birinin yer değiştirdiği belirtilmektedir ve bu süreçte iskân politikaları ağırlığını korumaktadır (Emek İnan, 2016: 16). Yunanistan ile yaşanan mübadele süreci kitlesel bir göç akınının yaşanmasına ve bu da Cumhuriyet tarihinin göçle ilgili ilk düzenleyici belgesi olan 1926 İskân Kanunu'nun oluşturulmasına neden olmuştur (Kirişçi, 2000: 3). Osmanlı döneminin Müslüman nüfus üzerinden hareket ederek dinî kimlik algısıly yönlendirilen iskân siyaseti, Balkan Savaşı ve sonrasında yayılan milliyetçi düşüncenin de etkisiyle, Türk kimliği üzerinden gerçekleştirilmeye başlanmıştır (Kirişçi, 2000: 3).

Türkiye için göç yönetiminin kritik adımlarından biri de 1934 yılında çıkarılan İskân Капипи olmuştur. Bir öncekine göre daha kapsamlı şekilde çıkarılan Kanun, göç yönetiminde muhacir tanımının yapılması bakımından büyük önem arz etmektedir. Kanunda muhacir, "dışarıdan Türkiye'ye yerleşmek amacıyla gelen aşiretler, Türk soyundan ve Türk kültürüne bağlılığı olanlar" şeklinde tanımlanmıştır. Muhacir tanımının yapılması yalnızca bu tanıma uyan kişilerin iskân ve vatandaşlık haklarından yararlanmaları bakımından önemli olduğu gibi, yine sadece bu kişilere göç etme hakkı tanınmasından dolayı da göç yönetiminin sınırları bakımından belirleyici olmuştur. Ayrıca Kanunda sadece muhacir tanımı yapılmamış, yine ülke dışından zorunlu sebeplerden dolayı gelen ancak yerleşme niyeti olmayan kişiler için de mülteci ifadesi kullanmıştır (İçduyguve diğerleri, 2009: 119).

Her iki kanun da sadece ülke dışından gelenlerin değil, aynı zamanda ülke içerisinde dağınık şekilde ya da sağlıksız koşullarda yaşayan kişi ya da toplulukların iskân edilmeleriyle ilgili düzenlemeler getirmiştir. Özellikle merkezlerden uzak konumda bulunan aşiretlerin daha düzenli yaşamaları hedeflenmiştir (Duman, 2009: 478-479). İskân konusunda dikkat edilmiş hususlardan bir diğeri ise güvenlik meselesidir. Hâlâ savaşın etkileri söz konusuyken, Bulgaristan tarafindan firsat bulunduğunda saldırı gelebileceği ihtimali üzerinde durulmuş ve buradan gelen 95.000 kişi Trakya bölgesine yerleştirilerek sınır güvenliği konusunda da atım atılmıştır (Sallan-Gül, 2002: 87).

\subsubsection{Pasaport Kanunu}

Göç yönetiminde yapılmış yasal düzenlemelerden bir diğeri ise Pasaport Kanunu'dur. 1950 yılında yürürlüğe giren kanun vasıtasıyla öncelikle ülkeye giriş yapacak olanlar için bir düzen oluşturulması amaçlanmıştır. Kanun incelendiğinde ilk üç madde, hem yabancıların hem de Türk vatandaşlarının ülkeye girişte kullanacakları belgeler ve muadilleri ile ilgilidir. Bir sonraki madde ise pasaport, vesika olmadan veya uyulması gereken diğer kurallara uymayanların sınır dışı edilmeleri ile ilgili düzenlemeyi içermektedir. 8. maddede ülkeye girmesi yasak olan kişi ve gruplar belirtilmiştir (Dönmez Kara, 2015: 166).

Kanun ülkeye giriş şartlarını düzenlerken bir yandan da şartlara uyulmaması halinde cezaî uygulamalara da değinmiştir. Ülkeye giriş ve çıkışlarda pasaport veya pasaport yerine geçebilecek bir belgeye sahip olmayanların, 33. maddede para cezası ile birlikte 3 aya kadar hapis cezasıyla yargılanacakları belirtilmiştir. Madde hem Türk vatandaşları hem de yabancılar için geçerliyken, yabancıların ceza sürelerinin dolumu sonrasında sınır dışı edilecekleri kanunda 
yer almıştır. Kanunda ayrıca devlet tarafından belirlenmiş sınır kapılarının dışında, farklı yerlerden ülkeye giriş ya da ülkeden çıkış yapılmaya çalışılması durumunda bunu yapmaya çalışan kişilerin para cezası ve 1 aydan 6 aya kadar hapis cezası ile yargılanabilecekleri hükmü yer almaktadır. Yine kanuna göre bu kişilerin sınır kapılarından farklı yerlerden geçmelerine yardımcı olanlar da 1 aydan 2 yıla kadar hapis cezasıyla karşılaşacaklardır (Pasaport Kanunu, 1950: $2370 \mathrm{~m})$.

\subsubsection{Cenevre Sözleşmesi}

Ulusal anlamda çıkarılan bir kanun ya da genelge olmasa da, Cenevre Sözleşmesi’nin Türkiye'nin göç yönetiminin çözümlenmesinde kritik öneme sahip olduğu söylenebilir. Sözleşmenin uluslararası göç bakımından önemi ilk defa küresel bir metinde yazılı olarak mülteci tanımının yapılmış olmasıdır. Sözleşme hazırlanırken masada olan taraflardan biri olan Türkiye, buna rağmen sözleşmeyi 10 yıl gecikmeyle 1961 yılında imzalamıştır (Cenevre Sözleşmesi, 1951). Türkiye sözleşmeyi imzalayarak uluslararası korumaya girmiş olsa da sözleşmeyi bazı maddelere çekince koyarak imzalamıştır.

Çekince koyulan maddelerin biri de, sözleşmenin herhangi bir hükmünden dolay1 Türkiye'de bulunan bir mültecinin Türk uyruklu bir kişiden daha fazla hakka sahip olamayacağ 1 hükmüdür. 1926 ve 1928 yıllarında imzalanan Ermeni, Rus ve Suriye asıllı mülteciler ile ilgili sözleşmelere taraf olunmayacağ 1 da yine Türkiye tarafindan deklare edilmiştir. Cenevre Sözleşmesi'nin ilk maddesindeki "1 Ocak 1951'den önce gerçekleşen olaylar ifadesi” bu tarihten önce "Avrupa' da gerçekleşen olaylar” şeklide değiştirilerek onaylanmıştır (Mültecilerin Hukuki Durumuna Dair Sözleşme, 1961: 181).

Sözleşmenin bu şartlarla birlikte onanmasında, özellikle Avrupa'dan gelenler ibaresinin eklenmesi dikkat çekicidir. Türkiye'ye olan göçlerin yoğunluğunun Avrupa dişında ülkelerden gelmesi sebebiyle, bu kişi ve topluluklara kendi hukuk sistemi içerisinde geçici sığınma hakkı tanıdığ1 yorumu yapılabilir (Ekşi, 2014: 66-67). 1967 yılında, Mültecilerin Hukukî Statüsüne İlişkin Protokol'de "1 Ocak 1951'den önce meydana gelen olaylar" ibaresi çıkarılarak, Türkiye ve diğer bazı ülkelerin yapmış olduğu coğrafi çekince koyarak sözleşmenin imzalanması durumu ortadan kaldırılmaya çalışılmıştır. Ancak 1951 sözleşmesine taraf olan ülkelere, aynı çekincelerle protokolü imzalama hakkının verilmesi tezat bir durum oluşturmuştur (Ergüven ve Özturanl1, 2013: 1017-1018).

\subsection{Türkiye Göç Tarihi}

Modern anlamda kitlesel göçlerle Cumhuriyet sonrasında karşılaşan Türkiye için göç hareketlerinin tarihi Osmanlı dönemiyle başlamaktadır. Osmanlı'nın jeopolitik konumuyla birlikte fetihlerin etkisi, ekonomik, sosyal ve siyasal olaylar çeşitli göç ve nüfus hareketlerine sebep olmuştur. Klâsik anlamda göç yönetiminde sözü edilen Yahudi göçleri en önemli örneklerden birini teşkil etmiştir. O dönem engizisyon baskıyla mücadele eden İspanya'daki Yahudilerin bir kısmı Portekiz'e bir kısmı ise Osmanlı'ya göç etmiştir (Rozen, 2010: 46-47). Kendi dinlerinden vazgeçmek istemeyen Yahudilerin, Osmanlı'da dinlerinin gereklerini yerine getirmek için İslâm dininin buyruğu altında yaşamaları gerekmekteydi. Bu şekilde hem ilk kısımda bahsedilen ekonomik ve sosyal yaşamı kalkındırmaya yönelik bir hamle hem de dinî entegrasyonun sağlanmaya çalışıldığı bir göç yönetiminden söz etmek mümkündür (Tekeli ve Erder, 1978: 46).

Cumhuriyet dönemine gelene kadar farklı göç akınları belirli süreler içerisinde gerçekleşmeye devam etmiştir. Osmanlı-Rus Savaşı sonucunda Kırım'ın 1783 yılında Ruslar tarafından alınması üzerine bölgede yaşayan çok sayıda Tatar Müslüman Osmanlı’ya doğru bir 
göç hareketi başlatmıştır (Barut, 2018: 163). İlerleyen dönemde 1828-1829 y1llarında yaşanan Osmanlı-Rus Savaşı da yeni bir göç dalgası ve nüfus hareketine sebep olmuştur. Rusların Rumeli bölgesine doğru gelmesiyle, o bölgede yaşayan birçok Rum ve Bulgar, Rusya'ya gönderilmiştir. Rusya için bu göç dalgası, ülke içinde ekonomik ve sosyal uyum çalışmaları yapılmasına ve aynı zamanda diğer devletlere karşı bir askerî güç oluşturulmasına neden olmuştur (Gülsoy, 1993: 21 23).

1853 yılında Osmanlı ve Rusya arasında yaşanan çekişme tekrar etkisini göstererek Kırım Savaşı'nın çıkmasına sebebiyet vermiştir. Kırım Savaşı'nın sona ermesiyle Osmanlı daha önce hiç yaşamadığı büyüklükte bir göç akınına şahit olmuştur. O dönem için Rus İmparatorluğu bünyesinde yaşayan 300.000 Kırım Tatarı olduğu ve Savaş sonunda bu nüfustan yaklaşık 200.000 kişinin Osmanlı'ya göç ettiği tahmin edilmektedir (Williams, 2000: 79-80). Kırım Savaşı'nın etkilerinin ilerleyen yıllarda devam ettiği belirtilmelidir. Nogay ve Çerkes göçmenlerin Osmanlı'ya göç etme/ettirilme çabaları da kritik öneme sahiptir. Göç edenlerin soğuk hava şartlarında zorluk çekmeleri ve birçok ailenin yaşamını yitirmesi uluslararası göç hareketlerinin zorluğu bakımından önemli örneklerden biridir. Osmanlı'nın böyle büyük bir göç dalgasıyla karşılaşması da, göç yönetimi ve göçmen entegrasyonu bakımından ciddi zorluklar yaşanmasına sebep olmuştur (Demirtaş, 2011: 20-21).

1877-1878 y1llarında yaşanan Osmanlı-Rus Savaşı'nın, Osmanlı için gerçekleşen en kapsamlı göç dalgalanmasına sebep olduğu söylenebilir. Osmanlı’nın mağlubiyetiyle sonlanan savaş 1.253.000 kişinin göç etmesine sebebiyet vermesiyle, Osmanlı'yı göç yönetimi bakımından zorlamıştır. Böyle bir göç dalgası karşısında öncelikle göçmenler için bir sağlı hizmeti oluşturulmaya çalışılmış ve barınma koşullarının iyileştirilmesi için çaba gösterilmiştir. Savaşın sonunda Berlin Anlaşması'nın imzalanmasıyla Bulgar Prensliğinin kurulması da, Osmanlı'ya doğru gerçekleşen göç hareketlerini sürekli bir niteliğe büründürmüştür. $\mathrm{Bu}$ sürekliliğin Osmanlı toplum yapısında büyük değişimlere sebep olduğu söylenmektedir (Ağanoğlu, 2001: 33; Efe, 2018: 22).

Tablo 1: Göç Mevzuatı Tablosu

\begin{tabular}{|l|l|}
\hline 1926 İskân Kanunu & $\begin{array}{l}\text { Balkanlardan gelen göçler ve mübadele sürecinde } \\
\text { barınma ve istihdam sorunları çözülmeye çalışılmıştır. } \\
\text { Ayrıca bazı aşiretlerin dağınık yaşamı bırakarak } \\
\text { yerleşik düzene geçirilmesi amaçlanmıştır. }\end{array}$ \\
\hline 1934 İskân Kanunu & $\begin{array}{l}\text { Göçmenlerin ekonomik olarak katkılarından } \\
\text { yararlanmaya devam edilmiştir. Göç olgusunda } \\
\text { güvenlik yaklaşımı öne çıkmış ve bu sebeple } \\
\text { Trakya'da Bulgaristan'ın saldırı olasılığına karşı } \\
\text { tampon bölge oluşturulmuştur. }\end{array}$ \\
\hline Pasaport Kanunu & $\begin{array}{l}\text { Yabancılar için hukukî bir şablon ortaya konmuş ve } \\
\text { ülkeye giriş çlkış şartları düzenlenmiştir. }\end{array}$ \\
\hline $\begin{array}{l}\text { Yabancıların Türkiye'de İkamet ve Seyahatleri } \\
\text { Yabancıların ülkede 1 aydan fazla kalması durumunda } \\
\text { ikâmet almaları zorunlu tutulmuştur. Ayrıca siyasi } \\
\text { mültecilerin özel olarak düzenlenmesi bakımından }\end{array}$ \\
\hline
\end{tabular}




\begin{tabular}{|l|l|}
\hline & $\begin{array}{l}\text { ülke hukukunda yeni bir düzenleme getirilmiş ve bu } \\
\text { kişilerin sadece İçişleri Bakanlığı'nın göstermiş } \\
\text { olduğu yerlerde barınabilecekleri kararlaştırılmıştır. }\end{array}$ \\
\hline Vatandaşık Kanunu & $\begin{array}{l}\text { Göç olgusuna daha korumacı ve güvenlik üzerinden } \\
\text { yaklaşılmış. Bir yabancının vatandaşlık kazanmak için } \\
\text { yerine getirmesi gereken şartlar zorlaştırılmıştır. }\end{array}$ \\
\hline 1994 İItica Yönetmeliği & $\begin{array}{l}\text { Ülke içerisinde sı̆ınmacı, mülteci olgularıyla ilgili ilk } \\
\text { kez hukukî bir belge yazılmıştır. Sınır güvenliğinin } \\
\text { altı çizilmiş ve olası bir göç yoğunluğunda } \\
\text { sığınmacılara izin verilmeyeceği açıklanmıştır. }\end{array}$ \\
\hline Yabancıların Çalı̧ma İzinleri Hakkında Kanun & $\begin{array}{l}\text { Yabancıların hangi şartlarda çalsşabilecekleri ve } \\
\text { hakları belirtilmiştir. Daha önce kanunlarda tanımları } \\
\text { yapılmış olan Türk soyundan gelen muhacir, göçmen, } \\
\text { mültecilerin yabancılar için belirlenen sürelerden } \\
\text { bağımsız olacakları belirtilmiştir. }\end{array}$ \\
\hline
\end{tabular}

\subsubsection{Cumhuriyet Dönemi Göç Hareketleri}

1912-1913 döneminde yaşanan Balkan Savaşları, hem Osmanlı dönemindeki göç hareketlerinin devamına hem de mübadelenin ilk örneğinin yaşanmasına sebep olmuştur. I. Dünya Savaşı'na giden süreçte, ulus-devlet modelinin gelişimi birçok ülke için homojen nüfus yapısının oluşturulmasını gerektirmiştir. Homojen nüfus yapısına sahip olmak için ya mübadele örneğinde olduğu gibi anlaşma yoluna gidilmiş ya da ülke içerisinde yaşayan yabancı kişi ve gruplar zor kullanılarak sınır dışı edilmeye çalışılmıştır. Böyle bir durumun içerisinde 1913 yılında Türkiye ile Bulgaristan arasında imzalanan mübadele anlaşması gereği 48.570 Müslüman, Osmanlı topraklarına göç ederken; 46.764 Bulgar da Bulgaristan'a gitmiştir (Ağanoğlu, 2001: 121-122).

Osmanlı için göç hareketleri Balkan Savaşları sırasında da sürmüş ve sadece Bulgaristan ile sınırlı kalmamıştır. Diğer ülkelerden göç dalgaları gelmeye ve Osmanlı da göç vermeye devam etmiştir. Cumhuriyetin ilânı sonrasında yapılan mübadele anlaşmasının önünün bu dönemde açıldı̆̆ iddia edilebilir. Balkan Savaşları'nın sona ermesiyle özellikle Yunan egemenliğinde olan topraklardan çok sayıda Müslüman kökenli insan Osmanlı'ya göç etmiştir. Osmanlı bu noktada gelenlerin Anadolu'da Rum nüfusun fazla olduğu yerlerde ikamet etmesine karar vermiştir. $\mathrm{Bu}$ karar sonrasında Rum nüfusta da hareketlilik yaşanması, iki ülkenin mübadele fikrine daha sıcak bakmasıyla sonuçlanmıştır. Ancak iki ülkenin karş1lıklı olarak taleplerinin uyuşamayacağı anlaşılınca, mübadele anlaşması gerçekleştirilememiştir. Olumsuz sonuca rağmen ilk başta da söylendiği gibi, ilerleyen dönemde yapılacak mübadelenin önü bu sayede açılmıştır (Çetin, 2010: 153-156).

Osmanl1-Rus mücadelesi ve Balkan Savaşları, Müslüman ve Hristiyan nüfus arasında gerilimi tırmandırmıştır. Müslümanlar bulundukları coğrafyayı terk ederek Osmanlı'ya gelmek istemiş, Osmanlı'da yaşayan Hristiyanlar da Anadolu'dan uzaklaşmayı istemişlerdir. Cumhuriyet ilân edildikten sonra gerçekleşen ilk büyük göç hareketi, Yunanistan ile Türkiye arasında mübadele yoluyla olmuştur. 30 Ocak 1923 tarihinde iki ülke arasında protokol imzalanmış ve mübadele hayata geçirilmiştir. Her ne kadar protokol imzalanması Cumhuriyet 
ilân edilmeden önce olsa da, iki ülke arasındaki mübadele 1927 y1lına kadar çeşitli dönemlerde sürmüştür. $\mathrm{Bu}$ süreçte Anadolu'da yaşayan 1.200.000 dolaylarında Rum ile Yunanistan'da yaşayan 400.000 Müslüman mübadele yoluyla ülkelerini değiştirmiştir (Yalçın, 2004: 109; İçduygu ve diğerleri, 2014: 100).

Mübadele süreci eleştirileri de beraberinde getirmiştir. Dönemin koşulları dünya genelinde ulus-devlet modelinin gelișimine olanak sağlarken, çoğu ülke bu modele göre homojen bir nüfus yapısı hedefi üzerine politikalar belirlemektedir. Zorunlu göç uygulamasının örneklerinden olan mübadele altında, etnik temizlik yapıldı̆̆ 1 iddiası gündeme gelmiştir. Ancak bu teze karşılık, I. Dünya Savaşı sonrası uygulanabilecek barışçıl yöntemlerden biri olduğu da belirtilmektedir. Ayrıca etnik temizlik fikrinin aksine, savaş sonrası koşullarda Yunanistan'ın ülke nüfusunu artırma isteğinin, mübadele fikrinin büyük devletlerce kabul gördüğü yorumu da yapılmaktadır (Efe, 2018: 21; Ortayl1, 2017).

Balkanlardan göçler 1960'lı yıllara kadar belirli aralıklarla gelmeye devam etmiştir. Yaşanan iki dünya savaşı sonrasında, daha barışçıl bir ortamda göç hareketleri yaşanmaya devam etmiştir. Cumhuriyetin ilânından 1960 yılına kadar geçen sürede Türkiye'ye yapılan göçlerin \%98'i Balkan göçleri olarak kayıtlara geçmiştir. Türkiye'nin düzenli ve çok sayıda Balkan göçüyle karşılaşmasında hem coğrafi yakınlığın etkisi belirtilmekte hem de Balkan ülkelerinde yaşanan siyasî istikrarsızlıkların sürmesi gösterilmektedir. Ayrıca din̂̂ inanç bakımından yakınlık olmasıyla birlikte kültür benzerlikleri ve dil bağlantısı da Balkan göçlerinin yoğun şekilde yaşanmasının sebepleri arasındadır. 1923 yılından 1950'li yılların sonuna kadar rakamlar incelendiğinde Bulgaristan, Yunanistan, Romanya ve Yugoslavya gibi ülkeler Türkiye'ye göç akınlarında başı çeken ülkeler arasında yer almaktadır (Akgündüz, 1998: 11-12).

1923 sonrasında homojen nüfus ve ulus-devlet inşası ülke içerisinde birçok alanda atılım ve gelişmeyi zorunlu kılmıştır. Bunu başarmak için adımlarını sıklaştıran Türkiye için yeterli akademisyen sayısının olmaması akademik ilerlemenin önünde engel teşkil etmiştir. Bu noktada Türkiye için göç hareketleri aynı zamanda üniversite reformunun gerçekleştirilebilmesi için dolaylı yoldan anahtar haline gelmiştir. 1930'ların başında yurt dışında yaşanan siyasî sorunlara paralel olarak Darülfünun'un dönüşüm süreci, yabanc1 akademisyenlerin desteğiyle gerçekleştirilmiştir. Sayısal olarak herhangi bir göç dalgasıyla kıyaslanamayacak kadar küçük bir grubun yer değiştirmesi olsa da, beyin göçü olarak adlandırılan göç türünün en keskin örneklerinden birine tanıklık edilmiştir.

Nazi Almanya'sında yaşayan bilim insanlarından bazıları ülkeden kaçmak istemiştir. Bu doğrultuda Türkiye'nin, sı̆̆ınma hakkının yanında çalışma hakkı da vermesiyle birlikte bilim insanları Türkiye'ye göç etmiştir. Almanya dışında Fransa, İtalya ve Avusturya gibi ülkelerden de kaçmak isteyen belirli sayıda akademisyen Türkiye'ye gelmiştir. Darülfünun'un İstanbul Üniversitesi'ne çevrilmesiyle, 1933 yılında üniversitede çalışan yabancı akademisyen sayısı 85'i bulmuştur. $\mathrm{Bu}$ durum üniversite reformuyla birlikte, farklı bilimsel alanlarda da gelişim sağlanmasına olanak vermiştir (Akgündüz, 1998: 113; Öztürk, 1999: 70-72).

Burada belirtilmesi gereken önemli hususlardan bir tanesi, yabancı bilim insanlarının öğrenme teknikleri konusunda büyük bir fayda sağladıklarıdır. Öğrenmeyi öğrenme ve kütüphanelerin zenginleşmesi gibi konularda ülkede bilimin gelişimine katkı sunulmuştur. Ayrıca katkıları bunun da ötesine geçerek çok sayıda öğrenci yetiştirmeleri, kalkınma odaklı yeni bir devletin ihtiyaç duyduğu nitelikli insan gücünü karşılamaya yardımcı olmuştur (Namal, 2012: 15-17).

Türkiye'nin ilk dönem göçlerine bakıldığında, Osmanlı'dan itibaren süregelen Balkan göçlerinin etkisi görülmektedir. Bu göçlere, nicelik olarak olmasa da, nitelik anlamında yabancı bilim insanların göçleri eklenmiştir. Modern anlamda uluslararası göç hareketlerine bakıldığında Türkiye için sürecin 1950-1960 döneminde başladığı söylenebilir. Bu dönemden itibaren göç 
alan ve göç veren ülke konumundaki Türkiye aynı zamanda transit ülke konumunda yer alırken, diğer yandan iç göç hareketlerinin de yükselmeye başladığı görülmektedir.

\subsubsection{0-1980 Dönemi}

II. Dünya Savaşı sonrası dönemde Türkiye için göç olgusu daha ön plana çıkmış ve önceleri olduğu şekliyle göç alan değil göç veren ülke konumuna doğru bir geçiş söz konusu olmuştur. 1960'a kadar genellikle, insanların bireysel düzeyde deneme ve zorlamalarıyla yurt dışına göçler şeklinde, bir göç hareketliliği oluşmaya başlamıştır. İlerleyen yıllarla birlikte farklı ülkelerle ikili anlaşmalar yapılmaya başlanması, bu göç hareketliliğini yurt dışına bir göç dalgasına dönüştürmeye başlamıştır. Avrupa ülkeleri özellikle II. Dünya Savaşı'nın bitimi sonrasında ekonomik olarak kalkınma sağlanması için iş gücü ihtiyacının bir kısmını ikili anlaşmalar üzerinden sağlamıştır. Türkiye özelinde bakıldığında, anlaşmalar yapılmadan önce, bireysel olarak Avrupa'ya gitmeyi başarmış meslek erbapları aynı meslekten başka kişileri yanına çekmişlerdir (Abadan-Unat, 2002: 40).

Türkiye için 1960 ve sonrası dönem siyasal, ekonomik ve sosyal olayların değiş̧imiyle ilerlerken, göç yönetimi de bu değişimden nasibini almıştır. Bu süreçte plânlı ekonomi döneminin başlamasıyla, dışa göç olgusu geçmişte olduğu gibi kişisel denemeler üzerinden değil, bir devlet politikası olarak gerçekleşmeye başlamıştır. İşgücünün hareket etmesiyle, özellikle yurt dışı kaynaklı döviz akışının ülkeye yönelecek olması, ekonomik kalkınmanın önemli finansal kaynaklarından biri haline getirilmek istenmiştir. Isşgücü göçünün sürekliliğinin sağlanması amacıyla, Türkiye, Almanya başta olmak üzere çeşitli Avrupa ülkeleriyle ikili anlaşmalar imzalamaya başlamıştır.

Sanayi devriminin gerçekleştirilmesi sonrası oluşan işgücü ihtiyacı o dönem Avrupa Devletleri tarafından Batı Avrupa üzerinden gelen göçmen akışı sayesinde giderilmeye çalışılmıştı. II. Dünya Savaşı sonrasında ise istihdam probleminin giderilmesi için Türkiye, Yunanistan, Yugoslavya gibi ülkelere yönelme eğilimi görülmüştür. $\mathrm{Bu}$ eğilim sonucunda Türkiye gibi ülkeler, durumu ekonomik kalkınma için temel bir politika haline getirmiş ve Avrupa genelinde bir işgücü hareketliliği süreci yaşanmıştır (Görmezöz, 2011: 41).

İlk olarak 1961 yılında Batı Almanya ile imzalanan ikili anlaşma çerçevesinde Türkiye'den iş̧̧i göçü gerçekleşmeye başlamıştır. Bu tarihten itibaren 1960'lı yılların sonuna kadar çeşitli Avrupa ülkeleriyle benzer anlaşmalar gerçekleştirilmiştir. Avusturya, Hollanda, Belçika, Ísviçre, Fransa, Ísveç, Danimarka gibi Avrupa ülkeleri Türkiye ile ikili anlaşmalar imzalamış işçi ihtiyacını bu şekilde gidermeye çalışmıştır. Türkiye de hem bireysel hem aile göçü şeklinde işgücü hareketliliğini devlet destekli politikalarla destekleyerek göç olgusunda ekonomi temelli bir yönetim modelinde ilerlemiştir.

1970'li yıllara kadar devam eden anlaşmalarla işgücü hareketliliği hem göç hem ekonomi alanında Avrupa ülkeleri için dönemin en önemli konu başlıklarından biri olmuştur. Ancak 1973 yılında yaşanan petrol krizi bu anlaşmalar ve göç akış1 için büyük sorun teşkil etmiş̧ir. Kriz sonrası işçi alımları çoğunlukla durma noktasına gelmiş ve ekonomik olarak duraksama yaşanmaya başlanmıştır. Bu noktada daha önceden göç etmiş ve yerleşik hale gelmiş̧ işçiler için ikili anlaşmaların yanına sosyal güvenlik anlaşmaları eklenmeye başlanmıştır. Kriz sadece göçmen iş̧̧i akışını kesmekle kalmayıp aynı zamanda çalışan işçilerin de işini kaybetmesine neden olmuştur. $\mathrm{Bu}$ dönemde çalışmaya devam edebilen göçmen işçilerin emeklilik, doğum yardımı, işsizlik maaşı, sağlık bakımı gibi hakları elde edebilmeleri için sosyal güvenlik anlaşmaları imzalanmıştır. Hem o dönem için hakların iyileştirilmesi hem de ilerleyen dönemler için göçmen işçilerin haklarının daha sağlam temeller üzerine oturtulması bakımından önem arz etmektedir (Abadan-Unat, 2002: 46-47). 
Petrol krizi sebebiyle birçok ülke için işgücü akışının sağlanması zora girmiştir ülke içerisinde başka sorunlara da yol açmıştır. Türkiye gibi hem ikili anlaşmalarla dışa göç veren hem de tarihi boyunca göç almış ve almaya devam eden bir ülke için dengeli bir nüfus politikası oluşturmak zorlaşmıştır. Kriz sonrasında hemen hemen tüm anlaşma imzalanan ülkelerin işçi alımını durdurmaya başlaması, aynı zamanda ülke içerisindeki istihdam rakamları bakımından da olumsuz sonuçlar doğurmaya bașlamıștır. Ancak bu durum, her krizin kendi içerisinde firsat yaratması sözünde olduğu gibi, Türkiye için yeni bir olanak getirmiştir. Bu sefer Avrupa ülkeleri yerine petrol sayesinde hızla zenginleşen Ortadoğu ülkelerinin işçi ihtiyacı ortaya çıkmıştır. Bu durum Türkiye'de bulunan vasıflı işgücü hareketinin başka bir yere kayması ve akışın devam etmesi anlamına gelmektedir (İçduygu ve diğerleri, 2014: 200).

Türkiye için bu dönem, her ne kadar devlet politikası sonucu dışa göç verilen dönem olarak anılsa da, diğer yandan uzun süredir devam eden göç alan ülke olma özelliği de devam etmiştir. Balkanlardan gelen göç akınları belirli aralıklarla etkisini sürdürmüş ve 1950 yılında Bulgaristan'dan 100.000 civarında aile Türkiye'ye bir kez daha kitlesel bir göç akını gerçekleştirmiştir. İlerleyen yıllarda mübadele örneğine benzer şekilde Bulgaristan ve Türkiye arasında anlaşma imzalanmış ve Türkiye yeniden 100.000 kişilik bir göç dalgasıyla karşılaşmıştır. 1960-1980 yılları arasında Balkan göçleri içerisinde her ne kadar resmî kayıtlarda geçmese de Yunanistan'dan gelen 20.000 Türk kökenli aile olduğu belirtilmektedir (Kirişçi, 2000: 9).

II. Dünya Savaşı sonrasından itibaren Türkiye için iç göç dalgalanmasından da bahsetmek gerekir. Kırdan kente göç akınları bu dönem içerisinde gerçekleşmeye başlamıştır. Türkiye gibi gelişmekte olan ülkelerdeki kır ve kent hayatı arasındaki farklılığın yüksek olması ve iki taraf arasındaki altyapı dengesizliği bu tarz yoğun iç göç hareketlerinin yaşanmasına sebep olmaktadır. Bu farklılıkların yanı sıra tarımda makineleşme oranının artması, kırsal yaşamda istihdam olanaklarının düşmesine ve işsiz kalanların çoğunlukla aileleriyle birlikte kente göç etmelerine neden olmaktadır. 1950 sonrasında sanayileşme yatırımlarının artması, kentlerde iş olanaklarının artışına sebep olmuş ve bu durum da yine kente göç akışını hızlandıran nedenler arasında yer almıştır (Tekeli, 2008: 75-77).

Tarımda makineleşme oranının artması, sanayileşme yatırımının hızlanması kente olan göçleri artırmış ancak bunun sonucunda çarpık kentleşme sorunu baş göstermiştir. Çarpık kentleşme ile mücadele edilememesi gecekondulaşma sorununu ortaya çıkarmıştır. Ayrıca sanayileşmeye yapılan yatırımın belli yüksekliğe ulaşmaması beklenen oranda bir istihdam alanı açmamıştır. Bu sebeple gecekondulaşma yanında istihdam sorunu da ortaya çıkmıştır. Ulaşım olanaklarının artışı hem küresel göç hareketlerinin hem de iç göç dalgalarının büyümesinde bir diğer sebeplerden kabul edilmektedir. Kırda üretim yapan kişi ve grupların artan ulaşım olanaklarını kullanarak kentli tüketiciye ulaşmasının kolaylaşması, yerelden ulusal piyasaya geçiş yapabilmesi de Türkiye iç göçünün yoğunlaşmasına neden olmuştur (Tekeli, 2008: 75-77).

\subsubsection{Sonrası Dönem}

1970’li yıllarda yaşanan petrol krizi daha önce de ifade edildiği üzere, dönemin işgücü akışını olumsuz anlamda etkilemiştir. Ancak bu kriz ilerleyen yılların göç akışında da neden olmuştur. Daha öncesinde yurtdışına giderek çalışmaya başlayan göçmen işçiler, yaşanan sıkıntılı sürecin ardından ailelerini yanlarına getirmekte zorlanmışlardır. Bu süreçte çoğunlukla ya yasal olmayan yollarla ya da siyasî mülteci olmaya çalışarak tekrar aile birleşimi sağlanmaya çalışılmıştır. Ayrıca 1980 yılında gerçekleşen askerî darbe de önemli faktör olmuştur. Darbe sonrasında yurt dışına gitmek isteyen çok sayıda insan, siyasî mültecilik için başvuruda bulunmuştur (Kirişçi, 2003). 
1980 sonrası dönemin Türkiye için en belirgin özelliğinin uluslararası göç hareketlerinde değişen konumu olduğu söylenebilir. Türkiye, Osmanlı'dan itibaren coğrafî konumu gereği transit ülke konumunda bulunurken, bir yandan da düzenli aralıklarla gelen Balkan göçleri sebebiyle göç alan ülke olarak nitelendirilebilir. Ancak 1980 ve sonrasında sınır komşusu olan ülkelerin yaşadığı iç karışıklıklar, siyasî sorunlar, Türkiye'ye olan göçlerin seyrini değiştirmiştir. Balkanlar, Türk etnik kökenliler ya da Türk kültürüne yakın topluluklar yerine, Türkiye artık sınır komşularının göç akınlarıyla karşı karşıyadır (İçduygu, 2006: 71-72).

Küreselleşme olgusunun iyiden iyiye etkisini hissettirmesiyle, göç akınlarının yoğunluğu da artmaya başlamış, Türkiye, daha çok Ortadoğu ve Afrika'dan gelen göçlere maruz kalmıştır. İslâm Devrimi sonrası ortaya çıkan iç karışıklıktan dolayı en yoğun göç dalgası Iran'dan gelmiştir. Türkiye'ye sığınmak için gelen İranlılar, ülkeyi transit ülke olarak kullanmaya çalışmışlardır. Türkiye'ye kalıcı olarak değil, Kuzey Amerika ülkeleri ya da herhangi bir Avrupa ülkesine geçişte kullanmak için gelmişlerdir. İran'dan gelen bu göç dalgasıyla ilgili kesin sayılar belirlenemese de, tahminlere göre o dönem gelen sı̆̆ınmacı sayısı 1.500.000 kişi dolaylarındadır (İçduygu, 2005: 7; Buz, 2008: 12).

1990 yılına gelmeden önce dikkat çeken diğer bir göç dalgası Afganistan'dan gelmiştir. Afganistan'ın 1979 yılında Sovyetler Birliği tarafından işgal edilmesiyle, çok sayıda Afgan Türkiye'ye gelmiş; İran'dan gelen göç dalgasında olduğu gibi, çoğunlukla, Avrupa ülkelerine geçiş yapmaya çalışmışlardır. Aynı dönemde Türkiye için Osmanlı'dan bu yana alışık olduğu bir göç akını tekrarlamıştır. Bulgaristan'dan 500.000 dolaylarında Türk, asimilasyon sebebiyle sığınmacı olarak Türkiye'ye gelmiştir. 1988-1991 yılları arasında gerçekleşen İran-Irak Savaşı, Irak'tan 600.000 kişinin gelmesine yol açmış ve bu kişilere Türkiye tarafindan korunma sağlanmıştır. Aynı zamana denk gelen Halepçe Katliamı da Türkiye'ye gelen göç yoğunluğunun artmasında rol oynamıştır (Manneart, 2003: 2-4).

1990'lı yıllara gelindiğinde Yugoslavya'nın dağılması ve Bosna Hersek olaylarının etkisiyle 20.000 kişinin sığınmacı olarak Türkiye'ye geldiği görülmektedir. 1999 yılında yaşanan Kosova Savaşı da Türkiye'ye olan göç yoğunluğunu artıran etkenler arasındadır. Bosna Hersek'te yaşanan olaylar sonrasında ülkede yaşayanların \%35'nin yer değiştirdiği belirtilmekte ve Türkiye'ye 25.000 kişilik bir grubun göç ettiği söylenmektedir (Deniz, 2011: 95).

Türkiye, 2000 ve sonrası dönemde, 1990'l1 yıllardan beri ülkeyi Avrupa ülkelerine geçiş amaciyla kullanan sığınmacılar ile mücadele etmiştir. Bu durumun zirve yaptığı 1995-2009 yılları arasında 800.000 düzensiz göçmen yakalanmış ve yakalananların yarısı kadarının Avrupa'ya geçmek isteyen sığınmacılar olduğu belirtilmiştir (İçduygu ve Sert, 2010: 7). Türkiye için düzensiz göçle mücadele esas itibariyle 2010 ve sonrası dönemde başlamıştır. Suriye'de yaşanan iç çatışma, Türkiye'nin sadece düzensiz göçle mücadelesini değil, aynı zamanda göç yönetimini de değişime zorlamıştır.

2010 yılında Arap Baharı'nın etkisiyle Türkiye için yeni bir kitlesel göç dönemi başlamıştır. Tunus'ta gerçekleşen olaylar sonrası Arap Baharı ismiyle anılan halk hareketleri 2011 yılında Suriye'ye sıçrayarak etkisini orada da hissettirmeye başlamıştır. Halk ayaklanmasına dönüşen olaylar neticesinde Suriye yönetiminin sert şekilde karşılık vererek ayaklanmayı bastırma çabası, silâhlı çatışmalara ve geri dönüşü zor olan bir sürecin başlamasına neden olmuştur. İlerleyen dönemlerde başka devletler ve ulus üstü kurumların devreye girmesiyle olaylar daha büyümüş ve 2000 sonrası dönemin en büyük göç dalgası başlamıştır. Birçok kişinin ölümü ve milyonlarca insanın zorunlu olarak göç etmesiyle Türkiye için yeni bir dönem başlamıştır (İnce, 2018: 43).

Küreselleşme sürecinin hızlanması, teknolojik ilerleme ve ulaşımda gelişim gibi faktörler; Türkiye için, başka ülkelerde olduğu gibi, göç hareketlerinin daha sık görülmesine neden olmuştur. Ancak Suriye gibi komşu ülkede yaşanan iç karışıklık Türkiye için daha önce 
yaşanmamış yoğunlukta bir göç dalgasına sebebiyet vermiştir. İlk etapta kurulan kamplarla Suriye'den gelen sı̆̆ınmacıların barınma sorunu giderilmeye çalışılmıştır. 2019 yılında Göç İdaresi Genel Müdürlüğ̈̈ (GIGM) tarafından paylaşılan rakamlara göre Türkiye'de kayıt altına alınmış Suriyeli sığınmacı sayısı 3.600.000'dir (GİGM, 2019).

2000 sonrası dönem Türkiye'de iç göç hareketlerinde kayda değer bir değişim yaşanmasa da, belli oranda görülmeye devam etmiştir. Kırdan kente göç olgusu değişim yaşamış; ekonomik sıkıntılar, işsizlik, yaşam koşullarının yetersizliği gibi sebeplerle kentten kente göç hareketleri daha çok gözlenmeye başlamıştır. Kırdan kente göç devam etmekte olup kırsal bölgede yaşayanların oranı düşerken, kentsel nüfus yoğunluğu artış göstermiştir.

\section{DEĞİŞEN GÖÇ SIYYASETİ: YABANCILAR VE ULUSLARARASI KORUMA KANUNU (YUKK) VE GÖÇ İDARESİ}

Türkiye için Osmanlı döneminden itibaren yaşanan göç dalgaları idarî düzenlemelerle yönetilmek istenen bir alan olmaya başlamıştır. İskân kanunlarıyla başlayan göç yönetiminin, yasal hale getirilmesi ilerleyen yıllarda farklı kanun ve yönetmeliklerde yapılan düzenlemelerle devam etmiştir. 1980 sonrasında sayıca büyüyen göç dalgalarıyla karşılaşılması ve göçün niteliğinin değişmesi, göç olgusunun çıkarılan yönetmeliklerle yönetilemeyecek kadar büyümesine neden olmuştur. 2010 yılı ve sonrasında ise Suriye'den daha önce karşılaşılmamış büyüklükte bir göç akınının olması, yasal düzenlemelerin de düzey atlamasını zorunlu kılmıştır. Gelinen noktada çıkarılan 6458 sayılı Kanun göç yönetiminin değişimini kanıtlar niteliktedir.

Yabancılar ve Uluslararası Koruma Kanunu (YUKK) çıkarılırken tek etkenin Suriye'den gelen göç dalgası olduğunu söylemek mümkün değildir. Aynı zamanda Avrupa Birliği (AB), göç ve göç yönetimi konusunda hem üye ülkelere hem de Türkiye gibi aday ülkelere, müktesebatlarında yapmaları gereken düzenlemeleri belirlemektedir. YUKK gerekçesinde de belirtildiği gibi, Türkiye için, $\mathrm{AB}$ müktesebatıyla uyumlu, insan haklarına saygıllı, idarî ve hukukî altyapının oluşturulduğu etkin bir göç yönetimine ihtiyaç vardır. (YUKK, 2013: 1-3).

Göç yönetiminde kapsamlı bir yasa yapılması daha önce çıkarılmış yasaların kaldırılması ya da bazı maddelerinin düzenlenmesi sonucunu doğurmuştur. Örneğin 1950 yılında yürürlüğe giren Pasaport Kanunu'nun bazı maddeleri ile Yabanciların Türkiye'de İkamet ve Seyahatleri Hakkında Kanun, YUKK sonrasında yürürlükten kaldırılmıştır. Bu iki kanun gibi, ayrı ayrı düzenlenmiş mevzuat, YUKK çıkarılarak bütünleşik ve daha etkin hale getirilmeye çalışılmıştır. Bu sayede kapsamlı bir düzenleme ve göç yönetiminde eksikliği hissedilen hukukî temelin oluşturulması amaçlanmıştır (Aygün ve Kaya, 2016: 99).

\subsection{Coğrafî Çekince Unsuru}

Türkiye'nin göç yönetiminde hukukî bir düzen oluşturmasında geçen gelişim sürecinde, ulusal mevzuat kadar uluslararası sözleşmelerin de etkisi büyüktür. Cenevre Sözleşmesi’ne taraf olunması küresel ölçekte plânlanan bir göç yönetim akışından uzak kalınmadığının göstergelerinden biridir. Ancak daha önce sözü edildiği gibi, sözleşme Türkiye tarafından coğrafî çekince konarak imzalanmıştır. Sözleşmede geçen ve sonrasında YUKK 4. Maddeye de eklenen "hiç kimsenin rrk, cinsiyet, dinî inanış ya da başka sebeplerle zarar görebileceği ve hayatının ya da özgürlüğünün tehdit altında olacağı bir yere gönderilemeyeceği” ifadesi, şüphesiz ülkeler için sığınmacı hukukunun temelini oluşturmaktadır. Böyle bir ifade ve bunun gerektirdiklerinin, kitlesel göçle karşılaşan ülkelere, maddî olduğu kadar manevî sorumluluklar yüklediği belirtilmektedir (Kaya ve Eren, 2014: 58). 
Göç edilen ülkenin bu kapsamda sahip olduğu sorumluluklar Türkiye için coğrafî çekince unsuru üzerinden bir eleştiri noktası oluşturmuştur. Sözleşmeyi coğrafî çekince koyarak imzalayan Türkiye, göç yönetiminde YUKK kapsamında yeni bir aşamaya geçerken bu konuda yeni/geri bir adım atmamıştır. YUKK 4. maddede kimsenin zarar görme ihtimalinin olduğu bir yere geri gönderilemeyeceği söylense de, coğrafî çekincenin bu durumla çeliştiği ifade edilmektedir. $\mathrm{AB}$ ile yapılan müzakerelerde de bu konu dile getirilmeye devam etmiş ve Türkiye'nin göç yönetim haritasının belirlenmeye çalışıldığ 1 Strateji Belgelerinde yer almıştır. $\mathrm{Bu}$ eleştiriler devam ederken konu üzerinde uzlaşı sağlanamamış ve YUKK 61. Maddede mülteci tanımı yapılırken yine "Avrupa'da meydana gelen olaylar" ifadesi tanımın önüne eklenerek coğrafî çekince unsuru korunmuştur (YUKK, 2013: M.61).

\subsection{Uluslararası Koruma}

Cenevre Sözleşmesi’nin kabul edilmesi ve AB üyeliği çalışmaları sırasında yapılan müzakereler doğrultusunda, etkin bir göç yönetimi çalışması evrensel tanımlar ve göç hukuku çerçevesinde gerçekleştirilmeye çalışılmıştır. Ancak coğrafî çekince unsuru hukukî anlamda da Türkiye için farklılık oluşmasına neden olmuştur. Bu noktada yeni çıkarılan kanunun 62 . Maddesinde şartlı mülteci tanımının yapıldığı görülmektedir. Şartlı mülteci tanımının ortaya çıkış sebebi, Türkiye'nin koymuş olduğu çekince olduğu için bu tanım aynı zamanda Türk hukukuna özgü olarak koruma statüleri arasında yerini almıştır (Çelik, 2015: 72).

Mülteci statüsü söz konusu olduğunda Türkiye Cenevre Sözleşmesi’ne koymuş olduğu coğrafî çekince şartı üzerinden Avrupa ülkelerinde meydana gelmiş olayları temel almaktadır. Şartlı mülteci statüsüyle Avrupa ülkeleri dışında gerçekleşmiş olayların temel alınacağı hukukî olarak belirtilmiştir. Bu sayede Suriye'den gelen yoğun nüfus hareketliliği karşısında göç yönetiminde atılan en önemli adımlardan birinin gerçekleştirildiği söylenebilir. Şartlı mülteci tanımının geçtiği maddenin devamında bir başka keskin hamle göze çarpmaktadır. "Türkiye'de şartlı mülteci statüsü almış kişi ya da kişilerin üçüncü bir ülkeye yerleştirilinceye kadar ülkede kalmalarına izin verilir" şeklinde devam eden madde metninden, bu statüdeki kişilerin ülkede geçici misafir olarak algılandıkları yorumu yapılabilir (Çelik, 2015: 76).

Mülteci statüsünde coğrafî çekince sebebiyle eleştirilen Türkiye için şartlı mülteci kavramı da eleştirileri beraberinde getirmiştir. Avrupa Insan Hakları Mahkemesi (AİHM)'nde uluslararası anlaşmalarla çelişki oluşturduğu üzerinden Türkiye aleyhine dava açılmıştır. Avrupa İnsan Hakları Sözleşmesi ortaya konarak Türkiye'nin uygulamaya çalıştığı modelin eşitlikçi olmadığı iddiası belirtilmiştir. Ancak coğrafî çekincenin baştan belirtilerek sözleşmenin imzalanmasının kural ihlâli bakımından sorun yaratmadığı sonucuna varılmış ve Türkiye için herhangi bir aleyhte hüküm doğurmamıştır (Ekşi, 2015: 49).

Göç yönetiminde YUKK kapsamında atılan koruma yönetmeliği adımları, geçici koruma maddesi de eklenerek geliştirilmeye çalışılmıştır. Aynı şartlı mülteci de olduğu gibi geçici koruma kavramı da Türk hukuku içerisinde YUKK ile birlikte kendisine yer bulmuştur. YUKK 91. Maddede ülkesinden ayrılmak zorunda kalarak acil ve geçici koruma bulma ümidiyle kitlesel olarak sınırlara gelen yabancılara geçici koruma sağlanabileceği hükmü yer almaktadır. Maddede dikkat çeken unsurun geçici korumadan bireysel olarak ülkeye giriş yapmaya çalışanların yararlanamayacak olmalarıdır. Kitlesel göç akınları içerisindeki kişilere verilmek üzere tasarlanan geçici korumanın çıkarılmasında Suriye'den gelen göç dalgasının etkisi yadsınamaz. Ancak maddeye coğrafî çekince ya da başka herhangi bir kısıtlama koyulmaması mülteci statüsü alamayan kişiler ve diğer olabilecek kitlesel göçler için hukukî bir altyapı oluşturması bakımından önem arz etmektedir (YUKK, 2013: M.91).

Geçici Koruma Yönetmeliği ile YUKK 6.maddede olduğu gibi geri gönderme yasağı koyulmuştur. Ölüm, işkence vb. sonuçlarla karşılaşma ihtimali olan kişilerin hiçbir sebeple geri 
gönderilemeyecekleri belirtilmiştir. Bu noktada Türkiye'nin göç yönetimi açısından iki zıt fikir ortaya atılmaktadır. Bir yandan mültecilik gibi bir statü elde edememiş insanların, geçici koruma statüsüyle bireysel ihtiyaçlarının karşılanabilecek olması hem insanî hem hukukî yönden önemli bir adım olarak görülmektedir. Ancak geçici koruma statüsünde bulunan kişilere ikamet izni verilemeyeceği hukuken düzenlenmiştir. Bu durum hem koruma türünün kapsamını daraltmakta hem de sığınmacılara olan bakış açısını olumsuz yönde etkilediği yorumu yapılabilmektedir (Geçici Koruma Yönetmeliği, 2014: m.6).

YUKK kapsamında koruma statüleri ve bu statülerin verilme şartlarıyla birlikte, uluslararası koruma statüsünün hangi koşullarda sona ereceği de belirtilmiştir. Terk edilmek zorunda kalınan ülkeye dönüş, kaybedilen vatandaşlı̆̆ın geri kazanılması, başka bir ülkeden vatandaşlık elde edilmesi gibi şartlar uluslararası korumanın sona erme durumları altında düzenlenmiştir.

\subsection{Göç İdaresi Genel Müdürlüğü}

Göç İdaresi Genel Müdürlüğ̈̈ (GİGM), YUKK 103. Madde kapsamında kurularak faaliyete geçmiştir. Kuruluş maddesinde belirtildiği gibi gö̧ konusunda politika ve strateji belirlemek, yabancıların ülkeye giriş çıkış işlemlerinin gerçekleştirilmesi, düzensiz göçle mücadele gibi işlemlerin yürütülmesi amaciyla kurulmuştur. Kuruluş maddesinin de gösterdiği şekliyle göç alanında uzmanlaşmış bir kurum ihtiyacının giderilmesi hedeflenmiştir. Göç yönetiminde Osmanlı dönemiyle başlayan, ilk hukukî adımların Cumhuriyet sonrası atılmasıyla devam eden süreç daha bütüncül bir yapı oluşturularak göç yönetiminde değişim hedefiyle devam etmektedir.

Asırlardır göç hareketleri ile karşılaşan bir coğrafyada göç yönetiminde önemli adımların atılmasının bu denli geç kalınmasında, göçlerin nitelik ve nicelik olarak farklılık göstermesi önemli bir sebeptir. Suriye'den gelen göç dalgası daha önce hiç karşılaşılmamış bir boyutta gerçekleşmiştir. Ayrıca 1980 sonrası dönemde İran, Irak, Afganistan gibi ülkelerden gelen göçmenlerin asıl hedefi Avrupa ülkelerine geçmek olduğu için göç yönetiminde esas özen gösterilen yer düzensiz göçle mücadele olmuştur. Ancak 2011 sonrasında gelen göçmenlerin çoğunluğu başka bir ülkeye gitmek isteseler de, Türkiye'de kalmak durumundadırlar. AB üyeliği kapsamında diğer birçok alanda olduğu gibi göç yönetiminde gelişim beklenmektedir.

GİGM öncesinde, uzun yıllar boyunca İçişleri Bakanlı̆̆ı'nın yanında Emniyet Genel Müdürlüğü'nün de nüfus hareketlerinde işleyişin başındaki kurum olması dikkat çekmektedir. Bunun sebebi olarak Türkiye'nin 2000 öncesinde çoğunlukla transit ülke konumunda bulunması ve yasa dışı yollardan göç etmeye çalışanların sayısının oldukça fazla olması olarak gösterilebilir. Ancak Suriye'den gelen yoğun göç sonrası Türkiye'nin hedef ülke haline gelmesiyle göç ve göç yönetimine bakış değişmek zorunda kalmıştır. Artık sadece kaçak şekilde göç etmek isteyenlerin engellenmesi ya da düzene sokulması göç yönetimi açısından yetersiz kalacaktır. Ülkeye gelmiş ve burada kalmak zorunda olan milyonlarca insanın öncelikle hukuk tarafindan taninarak statülerinin belirlenmesi, barınma ve istihdam gibi temel ihtiyaçlarının giderilmesi ve ilerleyen dönemlerde kültürel farklılıklardan dolayı ortaya çıkabilecek sorunların giderilmesi için bir entegrasyon çalışmasının yapılması elzem hale gelmiş, GİGM'nin kuruluşuna zemin hazırlamıştır.

YUKK 103. Maddeyle kurulan GİGM'nin görev ve sorumlulukları 104. Maddede belirtilmiştir. Genel hatlarıyla bakıldığında göç konusunda politika belirlemek, mevzuat gelişimini ve stratejilerin uygulanmasını sağlamak başlıca görevleri arasındadır. Yasa dışı göçle mücadele, geçici korumayla ilgili işlemlerin yürütülmesiyle birlikte göç alanında çalışacak ya da destek verecek kamu kurum ve kuruluşları arasında koordinasyon sağlamak ve bunlara destek olmak. Ayrıca ülkedeki yabancıların uyum süreçlerinin yürütülmesi de GİGM'nin görevleri arasında yer almaktadır (YUKK, 2013: m.104). 
Kanunla kurulan diğer bir kurum da Göç Politikaları Kurulu olmuştur. Göç yönetiminde izlenecek stratejinin belirlenmesinde İçişleri Bakanlığ ile birlikte çalışacak bir kurul oluşturulmuştur. Kurulun da görev ve sorumlulukları kanunda belirtilmiştir. GİGM'nin görevleri arasında bu kurulun sekretarya işlerini yürütmek maddesi yer almıştır. Bu noktada GİGM göç konusunda tek yetkili kurum olarak ortaya çıkmış ancak karar mekanizmasında Göç Politikaları Kurulunun olduğu gözlenmiștir. GİGM daha çok kurul ve bakanlık tarafından belirlenen yol ve yöntemlerin uygulanması ve izlenmesinde takipçi ve idarî işlerin sorumlusu olarak kendine bir yer edinmiştir. Ancak kuruldan verim alınıp alınamadığ tartışmalı bir konu olmuştur. 2018 yılı itibariyle Göç Kurulu ismini alarak yoluna devam etmekte ve daha önce belirtilen görev ve sorumluluklarının sınırlandırıldığı tespit edilmektedir.

GİGM'nin kurulmasıyla birlikte yine aynı kanunla müdürlüğe bağlı komisyonlar kurulmuştur. 81 ilde taşra teşkilatlanması gerçekleştirilmiş ve idarî işlemlerin yürütülmesi sağlanmıştır. Kurulan komisyonlar arasında; Göç Danışma Kurulu, Uluslararası Koruma Değerlendirme Komisyonu, Düzensiz Göçle Mücadele Koordinasyon Kurulu gibi komisyonlar yer almıştır.

GİGM'nün göç yönetimini bütüncül hale getirmesi ve yoğun göç dalgaları sonucunda göçmenlerin entegrasyonunu sağlaması istenmektedir. Müdürlük bünyesinde Uyum ve İletişim Dairesi Başkanlığ kurularak bu sorunun giderilmesi amaçlanmıştır. Suriye'den gelen sığınmacıların ilk olarak dil sorununu aşmaları için çalışmalar gerçekleştirilmiştir. Ayrıca çoğunluğu kamplarda olan sığınmacıların barınma, eğitim, sağlık gibi alanlarda da uyum ve toplumsal kabul sorunlarının çözümü öncelikli hale gelmiştir.

Müdürlük göç yönetiminde öncelikli hedeflerden biri olarak bürokratik işlemlerin azaltılmasını amaçlamıştır. Göç-Net uygulaması tasarlanmış ve bu sayede teknolojik açıdan göç süreçlerinde işlemlerin daha hızlı uygulanması sağlanmıştır. GİGM üzerinden vize ve ikamet başvuruları gibi işlemlerin çevrimiçi olarak gerçekleştirilebilmesi, hem zaman tasarrufu sağlarken hem de sürecin tek bir noktadan kontrolüne olanak vermektedir. Ancak bu durum şu an için yeterli görülmemekte ve daha çok işlemin internet veri tabanından gerçekleştirilmesi amaçlanmaktadır.

GİGM aynı zamanda ilerleyen dönemlerde gerçekleşebilecek olası göç hareketleri ve göç yönetiminin karmaşık hale gelmesi sebebiyle stratejik plânlar hazırlamaktadır. AB üyeliği sürecinde de önem verilen projeksiyonlar ilk olarak GIGM tarafından 2017-2021 yılları için tasarlanmış ve kamuoyuyla paylaşılmıştır (GİGM, 2016). Kurumun stratejik yönetim hedefi doğrultusunda gerçekleştirdiği bu uygulamalar, $\mathrm{AB}$ müktesebatına uyum çerçevesinde de olumlu yönde değerlendirilebilir.

Göç yönetiminde en etkin ve yetkili kurum olarak Müdürlüğün toplumsal görünürlüğü de önemli kıstaslar arasında yer almaktadır. Kurulduğu günden bu yana medya organlarında yer alması bakımından yeterliliği sorgulanmaktadır. Medya yoluyla gündemde kalmak uyum sürecinin bir parçası olarak kabul edilebilir. Uyum, sadece göç edenler için değil, aynı zamanda göç edilen ülke vatandaşları için de gerçekleşmesi gereken bir süreç olarak kabul edilmektedir. $\mathrm{Bu}$ süreçte Müdürlüğün görünürlüğü, uyum sürecinin etkin şekilde yönetilmesinde önemli bir faktördür. Bu konuda atılan ilk adımlardan birisi, mahalle etkinliklerinin gerçekleştirilerek sığınmacı ve yerleşiklerin adaptasyonunda çalışmalar yapmak olmuştur.

GİGM'nin basın yoluyla kendini görünür kıldığını iddia edebilmek pek mümkün gözükmemektedir. Göç ve göçmen ilişkisi basın yoluyla daha çok kendine yer bulurken, kurum geri plânda kalmıştır. Türkiye'nin göç siyasetine yön vermesi beklenen, göç yönetiminde en yetkin kurum olarak lanse edilen ve idarî işlem ve eylemlerin kendi çatısı altında gerçekleştirildiği bir kurum olarak göz önünde kalmayı başaramamıştır. Ayrıca kurum tarafindan hazırlanan Strateji Planında tanınırlık başlığının zayıflıklar kısmında yer alması dikkat çekicidir. 
$\mathrm{Bu}$ yönüyle lanse edilenin aksine, standart bir kamu kuruluşu olmanın ötesine geçme ihtimali düşük gözükmektedir.

\section{SONUÇ}

Türkiye için göç politikası oluşumunun Cumhuriyet ilân edildikten sonra gerçekleştiği yadsınamaz bir gerçektir. Göç politikası oluşurken içinde bulunulan dönemin hâkim koşullarının etkisi büyük olmuştur. İskân kanunları ile başlayan yasallaşma sürecinde Osmanlı döneminden itibaren gerçekleşen Balkan göçlerinin ve gelen Türk kökenli bireylerin etkisinden söz edilebilir. Yeni bir devlet oluşumu esnasında yabancıların göç hareketiyle karşılaşılmamış olunması sürecin nispeten rahat geçilmesini sağlamıştır.

İkinci dönem olarak kabul edilen sürecin Avrupa temelli bir ekonomik model üzerinden şekillendiği belirtilebilir. Yurt dışına gerçekleşen göç hareketleri ülke ekonomisi açısından fayda sağlayacağı düşünülerek kabul edilmiş ve desteklenerek bir devlet politikası haline getirilmiştir. 1980 ve sonrasına kadar kayda değer bir yabancı göçüyle karşılaşılmamış olunması, göç politikasında sadece Cenevre Sözleşmesi gibi bazı uluslararası yükümlülüklerin yerine getirilmesiyle yetinilmiş bir sürece sebebiyet vermiştir.

1980 sonrası Türkiye için hem göç hareketlerinin hem de göç yönetiminin değişmeye başladığı dönem olmuştur. Artık göç akınları, etnik yakınlık duyulan gruplardan çok, Türkiye için "çevre" sayılacak gruplardan gelmeye başlamıştır. Afganistan, Irak ve İran gibi ülkelerden gelen göçlerle karşılaşılması, düzensiz göçle mücadelenin ortaya çıkışı anlamına gelmiştir. Komşu ülkelerde yaşanan iç karışıklıklar, Türkiye'nin çoğunlukla transit ülke olarak kullanıldığı göç hareketlerine neden olmuştur. Avrupa ülkelerine göç etmek isteyenler için Türkiye bir geçiş noktası durumunda yer almıştır. Bu süreçte göç yönetimi; iskân kanunları sonrasında çıkarılan pasaport kanunu, vatandaşlık kanunu gibi ulusal ve Cenevre Sözleşmesi gibi uluslararası metinler çerçevesinde yürütülmeye çalışılmıştır.

Üçüncü dönemle başlayan ve Suriye'den gelen göç dalgasıyla iyiden iyiye ülkenin en önemli gündem maddeleri arasına giren göç yönetiminde politika oluşturma süreci dalgalı bir seyir izlemiştir. Avrupa'dan gelen eleştiriler de hesaba katıldığında coğrafí çekinceyle, oluşabilecek göç dalgalarına bir duvar örüldüğü söylenebilir. Bu noktada Avrupa ülkeleriyle ters orantılı giden bir süreç görülmektedir. 2010 sonrasında her ne kadar coğrafî çekince konusundaki tutum devam etse de, Suriye'den gelen büyük göç dalgası karşısında açık kapı politikası uygulanmıştır. Can güvenliğinin tehlikede olması temel alınmış ve milyonlarca sığınmacının ülkeye girişine izin verilmiştir. Avrupa'nın göç hareketlerine karşı duvar örmekle itham edildiği bir dönemde, Türkiye kapılarını açarak zıt yönde ilerlemiştir.

Türkiye için göç yönetimine dair hukukî ve idarî açıdan ihtiyaç duyulan düzenlemeler ancak 2010 sonrası dönemde yapılabilmiştir. Suriye'den gelen yoğun göç dalgası ve AB üyelik sürecinde uyulması gereken müktesebatla birlikte göç yönetiminde bir değişim gerçekleştirilmiştir. YUKK adında kapsamlı bir kanun çıkarılarak göç yönetiminde izlenecek şablon belirlenmeye çalışılmıştır. Aynı zamanda yine aynı kanunla Göç İdaresi Genel Müdürlügü kurularak göç yönetiminde kurumsal anlamda ilerleme gösterilmesi hedeflenmiştir. Bu noktada Türkiye için oluşan koşullar göç yönetiminin de seyrini belirlemiştir.

Türkiye için yaşanan değiş̧im, öncelikle hedef ülke haline gelmekten dolayı, güvenlik perspektifinde olmuştur. Cenevre Sözleşmesi'ne konan coğrafî çekince sebebiyle sığınmacılar, mülteci statüsü alamamış ve misafir algısıyla Türkiye'de bulunmuştur. Şartlı mülteci gibi bir terimin Türk hukukuna özgü şekilde ortaya çıkması da bu korumacı tavrın bir göstergesidir.

YUKK üzerinden bir göç politikası oluşturulurken, GİGM idarî bakımdan ön plâna çıkarılmaya çalışılmıştır. Yabancı vatandaşların tüm işlemleri tek kurum üzerinden yürütülmeye 
başlanmış ve işlerin kolluk kuvvetlerinden alınması amaçlanmıştır. Bu noktada, her ne kadar coğrafî çekince üzerinden korumacı tavır geliştirilmiş olunsa da, göç konusunda idarî iş ve eylemlerin kolluk kuvvetlerinden alınması olumlu karşılanmıştır. Bugün yoğun göç dalgaları karşısında kendini korumaya alan ve göç yönetiminde bütüncül bir yönetim hedefleyen bir Türkiye görülmektedir. Bu noktada GİGM tarafından yapılan işlerin görünürlüğünün daha fazla sağlanması amaçlanırken politika belirleme noktasında bir belirsizlik söz konusudur. Elbette Cumhurbaşkanlığı 1 ve İçişleri Bakanlığı ekseninde belirlenecek bir göç yönetimi olacaktır. Ancak Müdürlüğün ortaya çıkışında göç yönetiminde uzmanlaşmış bir kurumun olması en önemli sebeplerdendir. Dolayısıyla kurumun karar mekanizmasındaki yerinin daha keskin şekilde belirlenmesi ve daha etkin hale getirilmesi yapısal değişimin sürekliliği açısından göz önünde bulundurulmalıdır.

Geçmişten gelen korumacı yapının; mülteci statüsünün verilmesinde coğrafî çekincenin sürdürülerek geçici misafir gibi alternatif statüler yaratılmasına bakarak, devam ettiğini söylemek mümkündür. Ancak göç yönetimi, daha çok düzensiz göçle mücadele anlamı taşıyan Türkiye için bunun kısmen bir değişim olduğunu kabul etmek gerekir. Örneğin kolluk kuvvetleri üzerinden idare edilen yapının, sivil bürokratik bir yapıya devredilerek yönetilmeye başlanması değişimin en önemli ayağı olarak kabul edilebilir. Aynı zamanda, klâsik göç yönetiminin hassasiyetlerinin devam ettiği söylenebilir. Bu anlamda bir dönüşümden çok yeni koşullara uyumdan söz edilebilir. Ancak hem idarî hem de siyasal açıdan reform niteliği taşıyan düzenlemeler yapılmıştır.

\section{KAYNAKÇA}

Abadan-Unat, N. (2002). Bitmeyen göç konuk işçilikten ulus ötesi yurttaşlığa. İstanbul: Bilgi Üniversitesi Yayınları.

Ağanoğlu, H. Y. (2001). Osmanlı'dan cumhuriyet'e balkanların makûs talihi göç. İstanbul: Kum Saati.

Akgündüz, A. (1998). Migration to and fromTurkey, 1783-1960: Types, numbers and ethno-religious dimensions. Journal of Ethnic and Migration Studies. 24(1): 97-120.

Aygün, M. ve Kaya, C. (2016). Yabancılar ve uluslararası koruma hukukunda kalıcı bir çözüm olarak yerel entegrasyon. İn̈nü Üniversitesi Hukuk Fakültesi Dergisi. 7(1): 87-142.

Barut, I. (2018). Osmanlı dönemi’nde gerçekleşen göçlerin kurumsallaşma ve göç politikaları üzerindeki etkileri. Sosyal Politika Çalı̧̧maları Dergisi. 40(2): 161-190.

Buz, S. (2008). Türkiye'deki sığınmacıların sosyal profili. Polis Bilimleri Dergisi. 10(4): 1-14.

Çelik, N. B. (2015). Türk hukukunda uluslararası koruma başvurusunda bulunan veya uluslararası korumadan yararlanan yabancıların hak ve yükümlülükleri. İnönü Üniversitesi Hukuk Fakültesi Dergisi. 6(3): 67-148.

Çetin, N. (2010). 1914.Osmanl1-Yunan nüfus mübadelesi girişimi. Selçuk Üniversitesi Sosyal Bilimler Enstitüsü Dergisi. 24: 149-175.

Demirtaş, M. (2011). Osmanlıya gelen Kırım ve Kafkasya göçmenlerinin sorunları. Bilig-Türk Dünyası Sosyal Bilimler Dergisi. 57: 17-44.

Deniz, O. (2011). 1990 sonrasında Türkiye’ye yönelen sığınma hareketleri ve etkileri. TÜCAUM VI. Ulusal Coğrafya Sempozyuти Bildiriler Kitabı (ss. 93-102), Düzenleyen Ankara Üniversitesi Dil ve Tarih-Coğrafya Fakültesi. Ankara. 3-5 Kasım 2010.

Dönmez Kara, C. Ö. (2015). Göç bağlamında uluslararası işbirliği ve Türkiye’nin politikaları. (Yayınlanmamış Doktora Tezi). Çanakkale: Çanakkale On Sekiz Mart Üniversitesi Sosyal Bilimler Enstitüsü.

Duman, Ö. (2009). Atatürk döneminde balkan göçmenlerinin iskân çalışmaları (1923-1938). Ankara Üniversitesi Türk Inkllâp Tarihi Enstitüsü Atatürk Yolu Dergisi. 43: 473-490.

Efe, H. (2018). Osmanlı imparatorluğu ve Türkiye'de yaşanan göçler ve etkileri. Sosyal Bilimler Metinleri. 1: 16-27. 
Ekşi, N. (2014). Geçici koruma yönetmeliği uyarınca geçici korumanın şartları, geçici koruma usulü, sağlanan haklar ve geçici korumanın sona ermesi. İstanbul Barosu Dergisi. 88(6): 65-89.

Ekşi, N. (2015). Yabancılar ve uluslararası koruma hukuku. İstanbul: Beta Yayınları.

Emek İnan, C. (2014). Türkiye'de iskân siyaseti: iskâna yönelik örgütsel yapı üzerinden bir inceleme. Yönetim ve Ekonomi Araştırmaları Dergisi. 22: 82-102.

Emek İnan, C. (2016). Türkiye'de göç politikaları: iskân kanunları üzerinden bir inceleme. Göç Araştırmaları Dergisi. 2(3): $10-33$

Ergüven, N. S. ve Özturanl1, B. (2013). Uluslararası mülteci hukuku ve Türkiye. Ankara Üniversitesi Hukuk Fakültesi Dergisi. 62(4): 1007-1062.

Görmezöz, G. (2011). Uluslararası göç ve tarihsel gelişimi. İstihdamda 3i Dergisi. 3: 38-43.

Gülsoy, U. (1993). 1828-1829 Osmanlı-Rus savaşı'nda Rumeli'den Rusya'ya göçürülen reâyâ. Ankara: Türk Kültürünü Araştırma Enstitüsü.

İçduygu, A. (2005). Transit migration in Turkey: trends, patterns and issues. European University Institute.

İçduygu, A. (2006). Türkiye-Avrupa Birliği ilişkileri bağlamında uluslararası göç tartışmaları. İstanbul: TÜSİAD Yayınları.

İçduygu, A. ve Sert, D. (2010). Irregular migration at two borders: the Turkish-EU and Mexican-US Cases. German Marshall Fund Immigration Paper Series:1-18.

İçduygu, A., Erder, S. ve Gençkaya, Ö. F. (2014). Türkiye’nin uluslararası göç politikaları, 1923-2023: ulus-devlet oluşumundan ulus-ötesi dönüşümlere. MiReKoc Araştırma Raporları. 1: 2014.

İçduygu, A., Erder, S., Gençkaya, Ö. F. (2014). Türkiye'nin uluslararası göç politikaları, 1923-2023: ulus-devlet oluşumundan ulus-ötesi dönüşümlere. İstanbul: Koç Üniversitesi Göç Araştırmaları Merkezi.

İnce, C. (2018). Uluslararası göç politikaları: temel konular ve sorunlar. Toplumsal ve Siyasal Bilim Araştırmaları (ss. 4-51). İksad Yayınevi.

Kaya, İ. Ve Eren, E. Y. (2014). Türkiye'deki Suriyelilerin hukuki durumu arada kalanların hakları ve yükümlülükleri. Ankara: SETA Yayınevi.

Keleş, R. (1998). Kent bilim terimleri sözlüğ̈̈. Ankara: İmge Kitapevi.

Kirişçi, K. (1 Kasım 2003). Migration policy. https://www.migrationpolicy.org/article/turkey-transformationemigration-immigration, (10.03.2020).

Kirişçi, K. (2000a). Turkey: A country of transition from emigration to immigration. Mediterranean Politics. 12(1): 91-97.

Kirişçi, K. (2000b). Zorunlu göç ve Türkiye. Sığınmacı, Mülteci ve Göç Konularına İlişkin Türkiye’deki Yargl Kararlarl. Ankara.

Mannaert, C. (2003). New issues in refugee research (No. 89). WorkingPaper.

Namal, Y. (2012). Türkiye'de 1933-1950 yılları arasında yükseköğretime yabancı bilim adamlarının katkıları. Journal of Higher Education \& Science/Yüksekögretim ve Bilim Dergisi. 2(1): 14-19.

Ortayl1, İ. (03.09.2017). Her mübadele bir yaradır, izi kalır. Hürriyet Gazetesi. http://www.hurriyet.com.tr/yazarlar/ilber-ortayli/her-mubadele-bir-yaradir-izi-kalir-40568075, (01.02.2019).

Öztürk, A. O. (1999). Bir sığınak yeri olarak türkiye alman araştırıcıların 1933-1945 göçü. Selçuk Üniversitesi Edebiyat Fakültesi Dergisi (SEFAD). (13): 69-74.

Rozen, M. (2010). İstanbul Yahudi Cemaati'nin tarihi (1453-1566). Çev. Serpil Çağlayan. İstanbul: Türkiye İş Bankas1

Kültür Yayınları. 
Sallan-Gül, S. (2002). Dış göçler, yoksulluk ve Türkiye'de göçmenlere yönelik yardımlar. İnsan Hakları Yıllı̆̆ı. 2324: 79-93.

Tekeli, İ. (2008). Göç ve ötesi. İstanbul: Tarih Vakfı Yurt Yayınları.

Tekeli, İ., Erder, L. (1978). Yerleşme yapısının uyum süreci olarak iç göçler. Ankara: Hacettepe Üniversitesi Yayınları.

Williams, B. G. (2000). Hijra and forced migration from nineteenth century Russia to the ottoman empire. Cahiers du Monde Russe. 41(1): 79-108.

Yalçın, C. (2004). Göç sosyolojisi. Ankara: Anı Yayıncılık. 


\section{Extended Summary}

\section{Turkey's New Immigration Policy in the Context of Foreigners and International Protection Act and General Directorate of Migration Management}

With the impact of the globalization process increasing after the 1980s, migration movements have gained a new dimension. Both the density of population movements has increased and the places of countries in the migration phenomenon have started to change. Deglobalization period for Turkey, is considered as the period of change in the management of migration flows and migration. For the country, which has been intertwined with migration movements under the influence of its geographical location throughout history, Jewish migration in the Ottoman period is among the first striking migration movements. It was aimed that the Jews who were settled in Istanbul at that time would both make social life more lively and contribute to economic development. As of the 19th century, mostly Balkan migrations were encountered.

The resettlement policy, which was carried out in the early years of the Republic, is also a result of Balkan migrations. While harmonization efforts come to the fore with migration movements, the first target was to solve the accommodation problems by placing the immigrants of Turkish origin in the country. After immigration from the Balkans continued until the 1950s, the start of the immigration abroad was a new breaking point. Dispatching workers to Europe under agreements with European countries; In Turkey, it has caused the state to play an active role in guiding the migration flows. The period after 1980 for Turkey, it was a period when both migration movements and migration management started to change. In these years, migration flows started to come from outside of these, not from Turkish origin. Facing immigration from countries such as Afghanistan, Iraq and Iran has meant the emergence of the concept of combating irregular migration. The internal turmoil experienced in neighboring countries, Turkey has led to migration it had been used as a transit country. Turkey has become a transit point for people who want to immigrate to Europe.

In this process, after the settlement laws; Administrative regulations such as passport law and citizenship law have been implemented. In addition, Turkey has become a party in the international documents such as the Geneva Convention. Literally editing legal and administrative aspects management of migration in Turkey has coincided the post 2010 period. Along with the intense migration wave coming from Syria and the acquis to be complied with during the EU accession process, a transformation has been tried to be implemented in migration management. A comprehensive law called the Foreigners and International Protection Law (YUKK) was enacted to determine the template to be followed in migration management. At the same time, with the same law, General Directorate of Migration Management (GIGM) was established and it was aimed to make institutional progress in migration management. At this point the conditions made for Turkey has also determine the course of migration management. While establishing an immigration policy via YUKK, the GIGM was tried to be brought to the fore in administrative terms. All transactions of foreigners have started to be carried out through a single institution and it was aimed to get the jobs from law enforcement. At this point, although the protectionist attitude was developed over the geographical reservation, the removal of the administrative affairs in the field of migration from the law enforcement officers was welcomed. Today, it is desired to protect itself against intense waves of migration and to implement a holistic migration management. At this point, the visibility of the works done by GIGM should be increased. There is also an uncertainty at the point of policy making.

It is possible to say that the protective structure from the past continues. Arrangements such as maintaining geographical reservation in creating refugee status, creating alternative status such as temporary guests prove this. For Turkey, It should be accepted that this situation is partly a change. Because, in terms of Turkey migration management, refers to combating 
irregular migration. For example, the transfer of international migration managed by law enforcement to a civil bureaucratic structure can be considered as an important pillar of change. At the same time, it can be said that the sensitivities of the classical migration management continue. In this sense, it is possible to talk about adaptation to new conditions rather than transformation. However, reforms, both administrative and political, were made. 